\title{
ПРАГМАТИКА СУЧАСНОГО РЕКЛАМНОГО ТЕКСТУ
}

Хоменко Г. С. Прагматика сучасного рекламного тексту.

У статті порушено ряд питань, що стосуються сучасного рекламного тексту, зокрема його структурних та функційних особливостей. Розглянуто перлокутивний, прагматичний ефект висловлення. Проаналізовано психолінгвістичні чинники впливу, виражені засобами синтаксичного рівня мови.

Ключові слова: прагматика, рекламний текст, синтаксичні засоби мови.

Хоменко А. Е. Прагматика современного рекламного текста.

В статье поднимается ряд вопросов, связанных с современным рекламным текстом, раскрываются его структурне и функциональные особенности. Рассматривается перлокутивний, прагматический эффект высказывания. Анализируются психолингвистические факторы влияния, выраженные средствами синтаксического уровня языка.

Ключевые слова: прагматика, рекламный текст, синтаксические средства языка.

Khomenko H. Pragmatics of advertising text.

In the article the features of the advertising text on its structure and functions. Perlocutionary considered, pragmatic effect statements. Analyzed psycholinguistic factors influence expressed by means of syntactic level of language.

Key words: pragmatics, advertising text, syntactic means of language.

У наш час реклама стала невід'ємною частиною буття кожного індивіда, а рекламний простір являє собою безмежне поле для наукових досліджень.

У сучасній лінгвістиці велику увагу приділяють передусім жанрами реклами, з'ясуванню стилістичних, структурно-граматичних (композиційних) особливостей відповідних текстових зразків (Є.С.Кара-Мурза, Н. І. Клушина, Є. С.Корнілова, Ю. О. Гордєєв, М. М. Кохтев, Л. В. Мінаєва, А. Ю. Морозова та ін). Узаємозв'язку тексту та зображення в рекламі присвячено дослідження В. В. Волкової, О. Л. Тульсанова.

Окреслена проблема неодноразово була предметом зацікавлення й у зарубіжному мовознавстві (К. Л. Бове, У. Ф. Аренса, Ч. Г. Сендідж, В. Фрайбургер, К. Ротцолл, Д. Ф. Енджела, Р. Д. Блеккуела, П. У. Мінарді та ін). Однак попри всі намагання подати вичерпний лінгвістичний аналіз рекламних текстів чимало проблем так і залишаються остаточно не розв'язаними. А це підтверджує перспективність дослідження окресленої проблеми.

Як відомо, звуковий комплекс «реклама» використовується для позначення таких двох різних сторін рекламного процесу, як-от: 1) реклами як сфери людської діяльності; 2) реклами як готового продукту. Звідси й закономірне витлумачення: «Реклама - це відгалуження масової комунікації, у руслі якої створюються i поширюються інформативно-образні, експресивно-сугестивні твори, адресовані групам людей задля того, аби спонукати їх до потрібних рекламодавцю виборів і вчинку» [2, с. 303]. 
Не викликає принципових заперечень те, що рекламна інформація може розглядатися в кількох площинах: як масова інформація, як економічний інструмент, як форма психологічного впливу, як масова культура або навіть мистецтво. Відповідно, центральним поняттям у вивченні реклами залежно від позицій дослідника може ставати інформація, товар, мотив чи образ. Наше дослідження передбачає розгляд реклами переважно в ії психолінгвістичному аспекті, а саме через іiї вплив на споживача синтаксичними засобами мови.

Рекламний текст вирізняється насамперед такими характерними особливостями, як чіткість, лаконічність і динамічність. Крім того, його специфіку пов'язують із тим, що, по-перше, він містить інформацію про фізичну чи юридичну особу, товари, ідеї, послуги; по-друге, призначений для невизначеного кола осіб; по-третє, покликаний формувати або підтримувати інтерес до фізичних, юридичних осіб, товарів, ідей, послуг; по-четверте, сприяє реалізації товарів, ідей, послуг .

Рекламний текст $є$ «прагматичним текстом» на тій підставі, що в ньому актуалізуються певні комунікативні стратегії. «Прагматика вивчає умови, при яких людина використовує мовні знаки» [1, с. 317], зорієнтована на розуміння умов адекватного вибору і вживання мовних одиниць задля досягнення кінцевої мети комунікації - уплинути на партнерів у процесі їх мовленнєвого акту. А рекламний текст, власне, i являє собою мовленнєвий акт, у якому представлені адресант, адресат та об'єкт повідомлення - висловлення.

Теорія мовленнєвих актів, як один з головних розділів лінгвістичної прагматики, пов'язана з ім'ям Дж. Остіна, який привернув увагу до того, що проголошення висловлювання може бути не тільки повідомленням інформації, а й дією (наприклад, прохання, порада, застереження). У рамках цієї теорії було запропоновано розмежування понять локуція (акт говоріння), іллокуція (здійснення якогось акту під час говоріння) i перлокуція (уплив на почуття, думки та дії інших осіб й отримання результату - навмисного чи ненавмисного) [1, с. 315].

При здійсненні мовленнєвого акту реалізуються одночасно дві дії: власне проголошення висловлювання (локутивний акт) та іллокутивний акт. Інакше кажучи, крім передачі повідомлення, відбувається реалізація комунікативного наміру мовця. А рекламне висловлювання передусім призначено для здійснення того чи того впливу на слухача, тобто має перлокутивний, або прагматичний ефект.

Отже, прагматика рекламного тексту покликана відповісти на питання, чому споживач, незважаючи на критичність мислення, сприймає рекламу, підкоряється їй. Розглянемо механізм упливу реклами, запропонований К. Стронгом у 1929 р., утілений у формулі реклами AIDA, яка складається 3 чотирьох елементів: Attention (увага); Interest (інтерес); Desire (бажання володіти товаром); Action (дія, купівля). Зауважимо, що нині ця формула 
перетрансформувалася у структуру рекламного тексту: заголовок, основна частина, слоган та ехо-вислів.

Attention - здебільшого ключова фраза, представлена в заголовку. Interest - повідомлення, 3 якого споживач отримує інформацію про властивості товару, його переваги, унікальні, доступність, ефективність, засвідчене в основному рекламному тексті.

Desire - «навіювальна» частина рекламного тексту, утілена в слогані, мета якого - викликати бажання споживача придбати товар, послугу.

Action - висновкова частина рекламного тексту, маніфестована в реквізитах фірми (являє собою ехо-вислів). Автор цієї теорії відзначає, що задля повного досягнення ефекту недоцільно перебудовувати зазначений порядок елементів, щоб уникнути порушення задуму цілого повідомлення. Ми погоджуємося $з$ означеною позицією науковця, оскільки завдяки такій послідовності компонентів рекламного тексту заголовок актуалізує увагу потенційного споживача, основна частина раціонально або ірраціонально аргументує переваги свого об’єкту, слоган акцентує свідомість людини на головній унікальній властивості, закликає придбати об'єкт реклами, еховислів - дозволяє запам'ятати назву бренду.

О. С. Попова конкретизує прагматичну функцію реклами, акцентуючи на ii стратегіi: «...рекламна стратегія спрямована на зняття критичного сприйняття адресатом рекламного тексту та формування в нього позитивного емоційного настрою. При цьому читач розуміє, що реклама повинна продати йому товар, тобто він усвідомлює їі мету, проте не стратегію, яка залишається непомітною <..> однак призначена в кінцевому результаті спонукати адресата до придбання рекламованого товару» [3, с. 281]. Позитивне емоційне тло створюється через уплив на свідомість людини, зокрема на свідому та несвідому іiі частини. Об'єкт упливу - мотиви особистості.

Американський психолог Ч. Ален виділив як основні такі біогенні та соціогенні мотиви:

- біогенні: апетитна їжа, затишне оточення, позбавлення від болю, сексуальне задоволення, благополуччя близьких, схвалення 3 боку суспільства, перевага над іншими, подолання перешкод, гра;

- соціогенні: краса і смак, охайність, розважливість, цікавість, надійність і гідність, економність і вигода, освіченість та інформативність, працездатність, здоров'я.

3-поміж названих мотивів, що знаходяться на периферії, слід виокремити ядро цього утворення: мотив самоактуалізації, який має ряд синонімів - мотив престижу, мотивації досягнення успіху, потреба в повазі, схвалення з боку суспільства; мотив збереження свого «Я». Поведінкові реакції людини на інформацію, що впливає на неї, переважно визначаються підсвідомою протидією проникненню в їі внутрішній світ, руйнуванню їі образу, «утрати обличчя».

Рекламісти враховують очевидний факт - мотивація і вчинки споживача рекламної інформації насамперед пов’язані з його усвідомленою й одночасно 
неусвідомленою відповіддю на власне запитання: «Як те, що мені пропонують, допоможе мені чи вплине на інших, щоб мене сприймали так, як я хочу?» [4, с. 845]. Тому споживач завжди має потребу в товарах, що оцінюються позитивно поважними людьми, викликають замилування і навіть заздрість. А відтак ефективна реклама грунтується на людському честолюбстві.

Переконливість рекламного тексту залежить від вдалого сполучення всіх складових його компонентів: зображення, звуку, образу, словесної тканини. Однак найсильніше впливають вербальні засоби переконання.

Нас цікавить синтаксичний, психологічний та структурно-семантичний аспекти рекламного тексту. Розглянемо на прикладах: Cmyдія стилю Терра-Biва запрошує на навчання. Візажист. Стиліст. Імідж-консультант. Базове навчання та підвищення кваліфікащіiі. Модно. Престижно. Перспективно. Тільки у нас - стажування на телезйомках, фешн-показах, конкурсах краси. Навчайтеся у професіоналів (Інтер). Проілюстрований рекламний текст у своїй структурі містить заголовок Студія стилю Терра-Віва запрошує на навчання; основний текст і слоган Навчайтеся у професіоналів. У висловленні представлено безособові речення (Модно; Престижно; Перспективно), які апелюють до біогенних та соціогених мотивів людини: схвалення з боку суспільства - престижно; краси та смаку споживача та самоактуалізції в соціумі: модно; мотиву вигоди: перспективно. Слоган становить прямий заклик, виражений у формі конструкції, спонукальної за метою висловлювання, синтаксичним центром якої виступає наказовий спосіб головного члена речення, співвідносного з присудком.

Наступний приклад ілюструє ефективне використання складнопідрядних речень 3 підрядними мети в рекламній індустрії: Cneu̧іaлicmu Nuts розробили передові технологї відбору лісових горіхів. Вони винайшли найсучасніший спосіб очищення горіхів, щоб зберегти й чілими. I все заради того, щоб від кожного батончика Nuts ви отримували справжню цілогоріхову насолоду. Nuts - цілогоріхова насолода $(1+1)$.

Це речення стовідсотково обіцяє людині задоволення іiі бажань. Підкреслюється реалізація потреби: отримання справжньої насолоди. Споживач угамовує біогенний мотив апетитної їжі. Будова тексту теж триєдина: заголовок, основна частина, слоган.

Досить часто при створенні рекламного повідомлення використовують питальні речення, які створюють проблемну ситуацію. Наприклад: Відчуваєш, який голод? Спробуй Tоок. Солоненький, випечений крекер, щуо тане у роті. Tоок смачно тамує голод будь-де $i$ будь-коли. Tоок-завджи смачно, завжди туm (ICTV). Їх мета - залучити споживача до діалогу, змусити шукати відповідь й водночас запропонувати своє розв'язання проблеми у вигляді спонукального речення: Cnробуй Took. Ці синтаксичні засоби допомагають реалізувати соціогенний мотив здоров'я.

Уплив на домінуючий мотив - престижу, досягнення успіху, потребу економності та вигоди споживача демонструють такі приклади: Тільки для Вас в лініі магазинів «Сва»- справжні елітні парфуми за доступними 
цінами. Дізнайся про аромат тижня та придбай його за знижкою $25 \%$. «Сва» допомагає зекономити (1+1); Зробіть собі подарунки від себе та MTC. Тепер МTC повертає 30\% мобільного спілкування з того, що ви використали протягом попереднього місяия. Підключайтеся до МТС $i$ цілий рік отримуйте $30 \%$ спілкування в подарунок та безкоштовні дзвінки y мережі МТC. Для участі надішли sms на номер 25. МТC - на крок попереду (Інтер). Мотив успіху підсилюється введенням у тканину тексту речення, спонукального за метою висловлювання, синтаксичним центром якого є однорідні головні члени речення: Дізнайся про аромат тижня та придбай його за знижкою 25\%; Зробіть собі подарунки від себе та МТС... Підключайтеся до МТС $і$ иілий рік отримуйте $30 \%$ спілкування в подарунок. Структура тексту передбачає 3 компоненти, відсутній еховислів. Проте акцентування уваги споживача одразу на кількох мотивах повністю компенсує відсутність висновкового елементу.

Активно використовуються контекстуально неповні синтаксичні конструкції задля уникнення тавтології: Розріджує. Видаляє. Захищає. Лазолван - 3 кроки лікування кашлю (Інтер). У цьому разі односкладні речення сприяють розкриттю основних переваг предмета, який спершу не вказаний, але 3 контексту легко домислюється (принаймні, що йдеться про лікарський препарат). Це спричиняе стійке запам'ятовування функцій товару, та, головне, його назви. Ці конструкції зумовлюють звертання до біогенного мотиву уникнення болю та соціогенного мотиву досягнення здоров'я.

Отже, можна зробити висновок, що реклама - це продукт рекламної діяльності, який розраховано на перлокутивний ефект. Прагматична спрямованість будь-якого рекламного тексту полягає в необхідності спонукати адресата до певних дій: придбання товару, замовлення послуги. Ефективність рекламної кампанії залежіть від вербальних засобів упливу на мотиви споживача. На синтаксичному рівні ефект досягається за допомогою різних типів речень, зокрема й питальних чи спонукальних за метою висловлювання, за структурою складних, за складом головних членів речення - односкладних, за відсутністю необхідних членів речення - контекстуально неповних. Грунтовне дослідження синтаксичних особливостей рекламного дискурсу, вважаємо, $\epsilon$ перспективним й спонукає до подальшого осмислення проблеми.

\section{Література}

1. Коваленко Є. Рекламний дискурс: лінгвістичні аспекти вивчення / Є. Коваленко // Лінгвістичні студії: [зб. наук. праць]. - 2009. - Вип. 19. - С. 314-319.

2. Лянг О. Маніпулятивний вплив у дискурсі комерційної реклами / О. Лянг // Наукові записки: [зб. наук. праць]. - 2008. - Вип. 89. - С. 303-306.

3. Попова Е. С. Структура манипулятивного воздейтвия в рекламном тексте / Е. С. Попова // Екатеринбург: Известия Уральского государственного университета : [сб. научн. тр.]. - 2002. - №24. - С.276-288.

4. Хатмулина Р. С. Особенности печатного рекламного текста как единицы коммуникации / Р. С. Хатмулина // Вестник Башкирского университета: [сб. научн. тр.]. - 2009. - Вып. 3. - С. 844-847.

Стаття надійшла до редакиії 19.10.2010 p. 